\title{
RISK OF TICK-BORNE BACTERIAL DISEASES IN FORESTRY WORKERS OF TERNOPIL REGION (WESTERN UKRAINE)
}

\section{RYZYKO ZWIAZANE Z ODKLESZCZOWYMI BAKTERYJNYMI CHOROBAMI WŚRÓD PRACOWNIKÓW LEŚNICTWA OBSZARU TARNOPOLSKIEGO (UKRAINA ZACHODNIA)}

\author{
Mariia Shkilna $^{1(A, B, C, D, E)}$, Mykhailo Andreychyn $^{1(A, B, D, E)}$, Ivan Klishch $^{1(A, B)}$, \\ Mykhailo Korda ${ }^{1(A, B, D, E)}$, Igor Rogalsky ${ }^{1(D, F)}$
}

${ }^{1}$ I. Horbachevsky Ternopil State Medical University, Ukraine

Authors' contribution Wkład autorów:

A. Study design/planning zaplanowanie badań B. Data collection/entry zebranie danych C. Data analysis/statistics dane - analiza i statystyki D. Data interpretation interpretacja danych E. Preparation of manuscript przygotowanie artykułu F. Literature analysis/search wyszukiwanie i analiza literatury G. Funds collection zebranie funduszy
Tables: 2

Figures: 3

References: 15

Submitted: 2017 Jun 01

Accepted: 2017 Jun 22

\section{Summary}

Background. The aim of the study was to evaluate the awareness of Lyme borreliosis prevention and risk of being infected with the Borrelia burgdorferi in the forestry workers of Ternopil Region. To achieve the objective, serological tests were performed.

Material and methods. The studies were conducted by diagnosing serum in 348 employees of Ternopil Region for anti-Borrelia burgdorferi s.l. antibodies by ELISA test. The age of the examined persons ranged from 17 to 75 , mean age - 38.9 years. All the participants completed a questionnaire. The forestry workers were asked to state whether they noticed any symptoms compatible with Lyme borreliosis.

Results. 348 forestry workers employed in five forest inspectorates were examined for specific anti-Borrelia burgdorferi s.l. antibodies. With ELISA test, a positive or inconclusive result in at least one antibody was observed in $43.1 \%$ of the respondents ( $n=150$ of 348$)$ : IgM antibody - in $14.6 \%$ ( $n=51$ of 348), and IgG antibody - in $35.3 \%(n=123$ of 348). The largest number of respondents in the study group, i.e. $35.3 \%$, were bitten in the abdomen area. As for the methods of tick removal, most respondents pulled the tick out with fingers $(35.9 \%)$, while only $6.0 \%$ turned to a physician or nurse to have it removed. Erythema migrans $(47 \%)$ and pruritis (31\%) were the most frequent symptoms among the participants.

Conclusions. The absence of the official recognition of Lyme borreliosis as an occupational disease in Ukraine makes the study of prevention measures and their distribution in professional groups working in wooded areas an urgent matter. Providing the forest administration units with a sufficient number of tweezers or special loops for tick removal would certainly increase the protection of those exploiting forests against work-related tick-borne diseases.

Keywords: Lyme borreliosis, forestry workers, serology ELISA test, IgM, IgG, ticks, Ukraine

\section{Streszczenie}

Wprowadzenie. Celem pracy była ocena świadomości zapobiegania boreliozie z Lyme i ryzyka zakażenia Borrelia burgdorferi s.l. u pracowników leśnictwa w regionie Tarnopola. Aby osiągnąć wyznaczony cel, przeprowadzono testy serologiczne.

Materiał i metody. Badania obecności przeciwciał anty-Borrelia burgdorferi w surowicy przeprowadzono u 348 pracowników leśnict wa z regionu Tarnopola przy użyciu testu ELISA. Wiek badanych wahał się od 17 do 75 lat, średnia - 38,9 lat. Wszyscy uczestnicy wypełnili autorski kwestionariusz ankiety. Robotnicy leśni zostali poproszeni o podanie objawów przypominających te wywołujące boreliozę z Lyme.

Wyniki. 348 pracowników leśnych zatrudnionych w pięciu inspektoratach leśnych zbadano pod katem wystepowania specyficznych przeciwciał anty- B. burgdorferi s.l. Przy użyciu testu ELISA, stwierdzono pozy tywny lub niejednoznaczny wynik co najmniej jednego rodzaju przeciwciał u 43,1\% respondentów (n = 150 z 348): w tym, przeciwciała IgM - u 14,6\% (n = 51 z 348 badanych), i przeciwciała IgG - u 35,3\% (N = 123 z 348). Najwięcej respondentów w badanej grupie, tj. 35,3\%, zostało pogryzionych przez kleszcze w okolicę brzucha. Jeśli chodzi o metody ich usuwania, większość respondentów użyła palców $(35,9 \%)$, a tylko $6,0 \%$ zwróciło się do lekarza lub pielęgniarki po fachową pomoc. Najczęstszymi objawami wśród pacjentów to wystąpienie rumienia wędrującego (47\%) i świądu (31\%).

Wnioski. Brak oficjalnego uznania boreliozy z Lyme jako choroby zawodowej na Ukrainie sprawia, że badanie środków zapobiegawczych i ich dystrybucja w grupach zawodowych pracujących na obszarach zalesionych jest pilną kwestią. Udostępnienie jednostkom administracji leśnej wystarczającej liczby pincet lub specjalnych pętli do usuwania kleszczy z pewnością zwiększyłoby ochronę tych, którzy pracują przy eksploatacji lasu przed chorobami wywołanymi przez te pajęczaki.

Słowa kluczowe: borelioza z Lyme, pracownicy leśni, test serologiczny ELISA, IgM, IgG, kleszcze, Ukraina

Shkilna M, Andreychyn M, Klishch I, Korda M, Rogalskyy I. Risk of tick-borne bacterial diseases in forestry workers of Ternopil region (western Ukraine). Health Problems of Civilization. 2017; 11(2): 93-98. doi: 10.5114/hpc.2017.69025.

Address for correspondence / Adres korespondencyjny: Mariia Shkilna, I. Horbachevsky Ternopil State Medical University, m.Voli, 1, Ternopil, 46001, Ukraine, e-mail: nadiya20743@gmail.com, phone: +380352524492

Copyright: (C) 2017 Pope John Paul II State School of Higher Education in Biała Podlaska, Mariia Shkilna, Mykhailo Andreychyn, Ivan Klishch, Mykhailo Korda, Igor Rogalskyy. This is an Open Access journal, all articles are distributed under the terms of the Creative Commons Attribution-NonCommercial-ShareAlike 4.0 International (CC BY-NC-SA 4.0) License (http://creativecommons.org/licenses/by-nc-sa/4.0/), allowing third parties to copy and redistribute the material in any medium or format and to remix, transform, and build upon the material, provided the original work is properly cited and states its license. 


\section{Introduction}

Lyme borreliosis (LB) is a widely distributed zoonosis. The causative agents of LB are the members of Borrelia burgdorferi sensu lato complex spirochetes [1].The forested area in Ukraine covers 9.4 million ha, i.e. 15.6\% of the total land area. Forests in Ukraine are distributed unevenly. The largest forested territories are in north and west of the country. According to the Order of the Ministry of Health of Ukraine No. 133 from 19.07.1995, Lyme borreliosis (LB) is officially classified as a disease in the group of especially dangerous infections. However, at the same time, Lyme borreliosis is not officially recognized as an occupational disease, and thus forestry workers do not receive appropriate social security coverage [3]. The registration of Lyme borreliosis cases in Ukraine began in 2000, and the incidence of this disease in the country is increasing each year: 58 cases were reported in 2000, whereas in 2015 as many as 3413 [4].

The aim of the study was to assess the awareness of prevention against Lyme borreliosis and the risk of acquiring the disease in forestry workers of Ternopil Region. To achieve the objective, serological tests were done.

\section{Material and methods}

The study was carried out in Ternopil Region (Oblast), which is located in the western part of Ukraine. This region is endemic for Lyme borreliosis, because it is located in the zone of fertile soils, moderate continental climate and forest landscapes. Such an environment is conducive to maintaining the main tick vectors of Borrelia burgdorferi sensu lato - Ixodes ricinus ticks. The territories of Ixodes ricinus ticks are reduced to 57 settlements of the 15 (out of 17) districts of Ternopil Region [5].

348 foresters (aged 17-75 years old) from 5 subordinate forestry inspectorates (Berezhany, Ternopil, Chortkiv, Buchach, Kremenets) of Ternopil Region were examined for anti-Borrelia burgdorferi s.l. antibodies by means of ELISA test that determined the level of specific IgM and IgG immunoglobulins (Euroimmun AG, Germany). The kits enabled the detection of infections caused by 3 pathogenic genospecies: Borrelia garinii, Borrelia afzelii and Borrelia burgdorferi sensu stricto. The level of serum antibodies lower than $\leq 16 \mathrm{RU} / \mathrm{ml}$ (relative units $=\mathrm{RU}$ ) was considered to be a negative result, the results between 16 and $22 \mathrm{RU} / \mathrm{ml}$ were qualified as equivocal or "grey zone", whereas the levels higher than $22 \mathrm{RU} / \mathrm{ml}$ were classified positive, according to producer's instructions. All the seropositive workers were subjected to clinical examinations in the Department of Infectious Diseases and Epidemiology, Dermatology and Venereology, I. Horbachevsky Ternopil State Medical University, Ukraine. The consent to conduct the study was obtained at the Bioethical Committee of I. Horbachevsky Ternopil State Medical University.

All examined participants completed a questionnaire developed by the scientists from Poland [6] to which the authors of the presented study adhered. All respondents answered the questionnaire inquiries, compatible with international questionnaires, indicating: the number and places of Ixodes ricinus tick bites, methods of the tick removal from the body surface, the most frequent symptoms that appeared after being bitten, application of repellents during work in the forest, checking the body for ticks after coming back from the forest.

The results of the study were then analysed statistically. The $\mathrm{p}$ value $(\mathrm{p}<0.05)$ was assumed as statistically significant. The analyses were performed using software Statistica for Windows, Version 5.

\section{Results}

\section{Results of epidemiological studies}

In the study group, $18.9 \%$ of the foresters were bitten once, $38.8 \%$ of the respondents had been bitten repeatedly, while the remaining $28.4 \%$ do not remember being bitten in their lifetime (Tab. 1).

Table 1. Data of the tick bite episodes in adolescents taking part in the study $(n=348)$

\begin{tabular}{|c|c|c|c|}
\hline \multicolumn{2}{|c|}{ Data of the tick bites } & $\mathbf{n = 3 4 8}$ & $\mathbf{\%}$ \\
\hline \multirow{3}{*}{$\begin{array}{c}\text { No. of tick bite } \\
\text { episodes }\end{array}$} & once & 66 & 18.9 \\
\cline { 2 - 4 } & twice & 44 & 12.6 \\
\cline { 2 - 4 } & more than three times & 135 & 38.8 \\
\cline { 2 - 4 } & do not remember any bite & 99 & 28.4 \\
\hline
\end{tabular}




\begin{tabular}{|c|c|c|c|}
\hline \multirow{4}{*}{} & upper limbs & 50 & 6.0 \\
\cline { 2 - 4 } & Lower limbs & 83 & 23.9 \\
\cline { 2 - 4 } & chest & 76 & 21.8 \\
\cline { 2 - 4 } & back & 24 & 6.9 \\
\cline { 2 - 4 } & head & 1 & 0,3 \\
\cline { 2 - 4 } & neck & 45 & 12.9 \\
\cline { 2 - 4 } & abdomen & 123 & 35.3 \\
\hline \multirow{4}{*}{$\begin{array}{c}\text { Methods of } \\
\text { tick removal }\end{array}$} & removed by a physician or nurse & 21 & 6.0 \\
\cline { 2 - 4 } & removed by other person & 22 & 6.3 \\
\cline { 2 - 4 } & grasped with fingers and pulled out & 125 & 35.9 \\
\cline { 2 - 4 } & scrape off with a fingernail & 16 & 4.6 \\
\cline { 2 - 4 } & disinfected & 13 & 3.7 \\
\cline { 2 - 4 } & lubricated with fatty substance & 59 & 16.9 \\
\cline { 2 - 4 } & bite site disinfected after tick removal & 90 & 25.9 \\
\hline
\end{tabular}

* - results do not added up to $100 \%$ as some options were selected more than once

The largest numbers of the respondents (35.3\%) experienced a tick bite in the abdominal area. About the same percentage declared being bitten in lower extremities and chest (23.9\% and $21.8 \%$, respectively). Only 1 (0.3\%) respondent pointed to the head area stated the tick bite into a head area (Tab. 1).

As for the methods of tick removal, most respondents, 125 persons (35.9\%,) pulled the tick out with fingers; $90(25.9 \%)$ individuals disinfected the place of the bite with an antiseptic; 59 (16.9\%) - lubricated it with fatty substance. The fact that only $21(6.0 \%)$ respondents turned to a physician or nurse for help seems to indicate that some steps should be taken in this respect (Table 1).

\section{Serologic tests by ELISA}

Lyme borreliosis is a multisystemic disease manifested by skin, arthritis symptoms and neurological symptoms. It is a disease causes by genospecies of Borrelia burgdorferi sensu lato complex [7].

Anti-Borrelia burgdorferi IgM and IgG antibodies were examined in the forestry workers from 5 forestry inspectorates of Ternopol Region, western Ukraine in the years 2015-2016. IgM antibodies were found in 36 of the examined workers (10.3\%); in 15 workers (4.3\%) the results were equivocal. In 108 persons (31.0\%), they turned out to be positive for IgG, while in 25 persons $(7,2 \%)$ they remained in the "grey zone" (Tab. 2).

Table 2. IgM and IgG antibodies in the forestry workers of the examined inspectorates (n=348) - ELISA test results

\begin{tabular}{|c|c|c|c|c|}
\hline \multirow{2}{*}{ No. } & \multicolumn{2}{|c|}{ Antibodies against $B$. burgdorferi } & \multirow{2}{*}{$\mathrm{n}$} & \multirow{2}{*}{$\%$} \\
\hline & $\operatorname{IgM}$ & IgG & & \\
\hline 1 & positive & positive & 26 & 7.5 \\
\hline 2 & positive & negative & 9 & 2.6 \\
\hline 3 & equivocal & positive & 6 & 1.7 \\
\hline 4 & positive & equivocal & 1 & 0.3 \\
\hline 5 & equivocal & equivocal & 1 & 0.3 \\
\hline 6 & negative & positive & 76 & 21.8 \\
\hline 7 & equivocal & negative & 8 & 2.3 \\
\hline 8 & negative & equivocal & 23 & 6.6 \\
\hline 9 & negative & negative & 198 & 56.9 \\
\hline \multicolumn{3}{|c|}{ Total } & 348 & 100.0 \\
\hline
\end{tabular}

The most frequent symptoms in the participants of the study were erythema migrans (47\%), pruritis (31\%), and other symptoms (5\%). 36\% of the respondents did not complain of any ailments. 


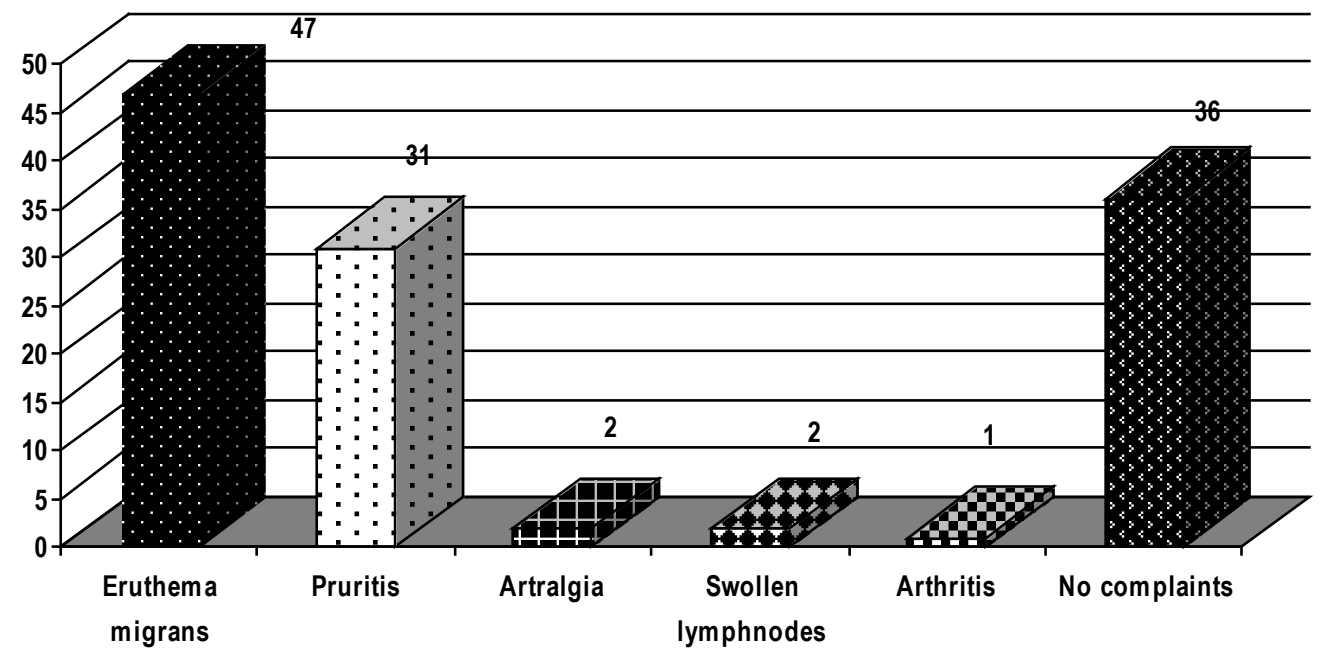

Figure 1. Most common symptoms of the disease appearing after tick bites

The fact that almost $88 \%$ of the respondents of 5 forestry inspectorates of Ternopil Region never used any tick repellents, in contrast to $3 \%$ who always applied them, requires consideration and some action (Figure 2).

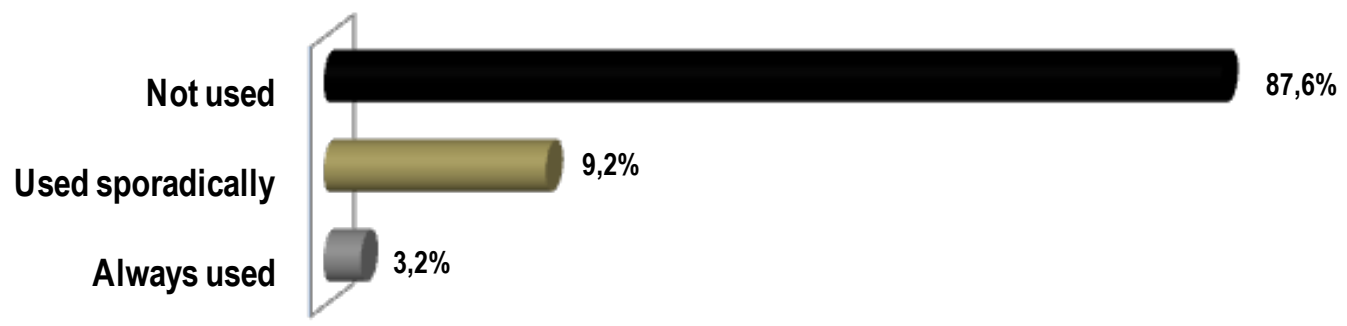

Figure 2. Percentage of forestry workers in Ternopil Region who use repellents during work in a forest area

As for examining one's skin after coming back from a forest area, almost $50 \%$ of the respondents stated that they checked their body for ticks after returning home (Figure 3).

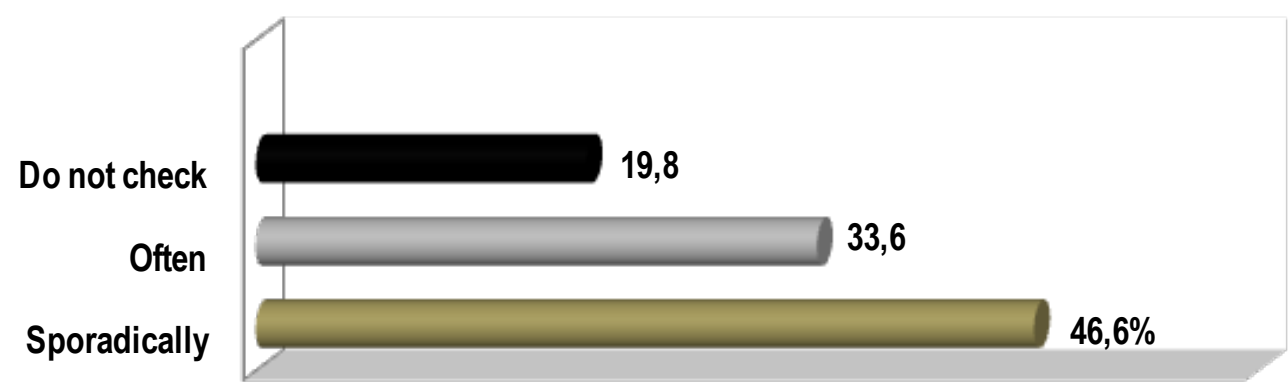

Figure 3. Checking the body for ticks after coming back from a forest area

\section{Discussion}

The detected positive results for IgM and IgG antibodies with ELISA test in forestry workers of the examined inspectorates of Ternopil Region, i.e. 10.3\% for IgM and 31.0\% for IgG, are comparable with the results obtained in different regions of Poland. In south-eastern Poland, the percentage of specific anti-Borrelia burgdorferi antibodies in forestry workers' blood serum reached 40\% [8], in Lower Silesia - 35.0\% [9], and in Southern Podlasie, I ranged from 7.8 to $15.6 \%$ [5]. In other European countries, the percentage of forestry workers and other employees particularly exposed to tick bites with detected antibodies against B. burgdorferi s.l. varied. For example, in Germany it ranged from $18 \%$ to 52\% [10] and in Slovakia, it stood at $12.8 \%$ [11]. In France, the antibodies were found in $14.1 \%$ of the examined persons who are exposed to contact with ticks due to their 
occupation, with the highest number of positive results found in logging workers (17.5\%) [12]. The results of the questionnaire strongly prove that forestry workers are at the greatest risk of being bitten by bites and of spreading tick-borne pathogens.

As for the site of the bite, it must be mentioned that most frequently it is the skin of lower limbs, buttocks, groins and abdomen, and a head area in children [13]. In the presented study, the largest group of respondents $(35.3 \%)$ were bitten in the abdomen area, and only $1(0.3 \%)$ respondent pointed to the head.

Statistically speaking, about two thirds of patients with Lyme disease have removed the tick improperly [14]. In the presented study, various methods of tick removal were mentioned. The most frequent one turned out to be pulling the tick out with fingers (35.9\%), 25.9\% mentioned disinfecting the bite site after tick removal, whereas only $6.0 \%$ of the respondents asked for professional assistance. The use of improper methods of tick removal increases the potential risk of spirochetal infection [13], and the reported methods of its removal are often inappropriate. Therefore, education proper behaviour after being bitten by the vector should become an important element of prevention actions in the regions affected by Lyme borreliosis. Therefore, providing the forest administration units with a sufficient number of tweezers or special loops for tick removal, available on the market, would certainly increase the safety of forest exploitation workers and protect them against workrelated tick-borne diseases.

As the data of symptoms compatible with Lyme borreliosis indicate, the most frequent symptoms in the forestry workers in Ternopil Region were erythema migrans (47\%) and pruritis (31\%), which is consistent with the findings of some other research done in Poland [15].

\section{Conclusions}

1. Specific IgG and/or IgM antibodies against Borrelia burgdorferi sensu lato were detected in 150 (43.1\%) out of the 348 examined forestry workers by means of ELISA test.

2. Only $12.4 \%$ of the participants applied preventive measures against tick bites, which means that there is a need to enhance the awareness in this professional group.

3. Providing the forest administration units with a sufficient number of tweezers or special loops for tick removal would certainly increase the safety of forest exploitation workers and protect them against workrelated tick-borne diseases.

4. The absence of the official recognition of Lyme borreliosis as an occupational disease in Ukraine makes that studying prevention methods and disseminating the information about the findings among professional groups working in wooded areas has become an urgent matter.

\section{References}

1. Geller J, Nazarova L, Katargina 0, Golovljova I. Borrelia burgdorferi sensu lato prevalence in tick populations in Estonia. Parasit Vectors. 2013, 9(6): 202.

2. Lunemann JD, Zarmas S, Priem S, Franz J, Zschenderlein R, Aberer E, Klein R, Schouls L, Burmester GR, Krause A. Rapid typing of Borrelia burgdorferi sensu lato species in specimens from patients with different manifestations of Lyme borreliosis. J Clin Microbiol 2001, 39: 1130-1133.

3. Andreychyn M. Lyme borreliosis. In: Andreychyn M, Vasylieva N, Kopcha V. Professional infectious diseases. Kyiv: Avicenna; 2014. p. 406-419.

4. http://www.terses.gov.ua/index.php/sanitarno-osvitni-pytannia/21-khvoroba-layma-berezhitsya-ukusivklishchiv [cited 2016 Nov 27].

5. Shkilna M. Lyme borreliosis in forestry workers of Ternopil region. Infectious Diseases. 2016; 1(83): 36-40.

6. Pańczuk A, Kozioł-Montewka M, Tokarska-Rodak M. Exposure to ticks and seroprevalence of Borrelia burgdorferi among a healthy young population living in the area of southern Podlasie, Poland. Ann Agric Environ Med 2014, 21: 512-517.

7. Kondrusik M, Grygorczuk S, Skotarczak B, Wodecka B, Rymaszewska A, Pancewicz S, et al. Molecular and serological diagnosis of the Borrelia burgdorferi infection among patients with diagnosed erythema migrans. Ann Agric Environ Med 2007, 14: 209-213.

8. Cisak E, Chmielewska-Badora J, Zwoliński J, Wójcik-Fatla A, Polak J, Dutkiewicz J. Risk of tick-borne bacterial diseases among workers of Roztocze National Park (southeastern Poland). Ann Agric Environ Med 2005, 12: 127-132.

9. Dobracki W, Dobracka B, Paczosa W, Zięba J, Bereś P: Epidemiology of borreliosis in workers of the district forestry offices in Lower Silesia. Przegl Epidemiol 2007, 61(2): 385-391 (in Polish). 
10. Oehme R, Hartelt K, Backe H, Brockmann S, Kimmig P. Foci of tick-borne diseases in southwest Germany. Int J Med Microbiol. 2002, 33:22-9.

11. Bazovska S, Machacova E, Spalekova M, Kontrosova S. Reported incidence of Lyme disease in Slovakia and antibodies to B. burgdorferi antigens detected in healthy population. Bratisl Lek Listy 2005, 106: $270-273$.

12. Thorin C, Rigaud E, Capek I, André-Fontaine G, Oster B, Gastinger G, et al. Seroprevalence of Lyme borreliosis and tick-borne encephalitis in workers at risk, in Eastern France. Med Mal Infect 2008, 38(10): 533 -542 (in French).

13. Bartosik K, Kubrak T, Olszewski T, Jung M, Buczek A. Prevention of tick bites and protection against tickborne diseases in south-eastern Poland. Ann Agric Environ Med. 2008; 15: 181-185.

14. Slimību profilakses un kontroles centrs. Informācija un ieteikumi izglītības iestādēm ērču pārnesto slimību profilaksei. [cited 07 June 2017]. Available from: http://www.spkc.gov.lv/ieteikumi-skolam-unbernudarziem/905/informacija-un-ieteikumi-izglitibas-iestadem-ercu-parnesto-slimibu-profilaksei (in Lithuanian).

15. Dybowska D, Kozielewicz D, Abdulgater A. Rozpowszechnienie boreliozy wśród pracowników lasów województwa kujawsko-pomorskiego. Rev Epidemiol. 2007; 61: 67-71 (in Polish). 